\title{
Designing Minangkabau Idiomatic Expression Comic Strips for Cultural Literacy
}

\author{
T Immerry ${ }^{1}$, F Dahlan ${ }^{2}$, H N Hidayat ${ }^{3}$, Wasana ${ }^{4}$, Pramono $^{5}$ \\ $\left\{\right.$ 1 immerry20@bunghatta.ac.id, ${ }^{2}$ femmydahlan@bunghatta.ac.id, ${ }^{3}$ herrynh@ @um.unand.ac.id, \\ ${ }^{4}$ wasana@hum.unand.ac.id, ${ }^{5}$ pramono@hum.unand.ac.id \} \\ ${ }^{1,2}$ Universitas Bung Hatta Padang, Indonesia \\ 3,4,5 Universitas Andalas Padang, Indonesia
}

\begin{abstract}
Minangkabau is one of the tribes in Indonesia that tends to use figurative language. However, as technology advances, its use has begun to diminish. one of the reasons is the young generation's lack of understanding of the meaning of the figurative language. This paper describes the effort to enhance the knowledge and understanding of Minangkabau idioms. The use of Minangkabau idioms is now suspected to be diminishing due to the limited knowledge of the younger generation of the idiom meaning. One attempt to reintroduce the meaning of the Minangkabau idiom is through transformation into an image form. This research collects idioms that are directly related to daily life. Selected idioms that carry moral contents and daily life guidance are transformed into visual forms, comic strips, and illustrations. It is expected, the transformation will increase knowledge and facilitate the understanding of the younger generation, especially towards the Minangkabau idioms. In other words, this research is one of the efforts to revitalize and socialize Minangkabau traditional culture.
\end{abstract}

Keywords: Comic Strips, Idiomatic Expression, Minangkabau, Literacy

\section{INTRODUCTION}

Idioms, or a group of words, are metaphoric and symbolic. They are meant to express something but by using other things, symbols, or commonly known as figurative language. This is what differentiates idioms from other group of words (phrases and compound words). Other forms of expressions that are commonly known include proverbs, bywords, sayings, petitih, bidal, and others. In terms of forms and meanings, idioms are a group of words not deducible from individual words that establish them.

Due to their symbolic nature, idioms are considered difficult to understand. Utami and Munir [1] concluded after conducting a research that the connection between texts and contexts in statements that use idioms are crucial to gain meaning. Pratiwi [2] stated that revealing the meaning of idioms uttered in the daily life are often difficult to do as they require knowledge, sensitivity, and intelligence in connecting the texts and contexts.

Due to the complexity of their elements, many idioms emerge as learning tools about the daily life, especially in traditional societies. Sartini [3] gained identified five Javanese local wisdoms in the idiom bebasan, seloka, dan paribasan, or politeness, energy, inter-human relationship, relationship between man and God, and bad behavior. Haryanto [4] also stated that traditional idioms play a key role in maintaining relationships among people of different 
faiths. Meanwhile, Hamid [5] discovered seven citizenship themes in a study on idioms in Sundanese language, which are hospitality, politeness, self-awareness, humbleness; patience, sincerity, whole-heartedness, transparency, straight/honesty; friendly, likes to help; dedication, readiness and alertness; firm in defending honor, gallant, bold and courageous; diligence, persistence, steady, quality-oriented (hard working and smart); fair and wise.

Compared to metaphors, idioms are more complex as they are comprised of a group of words. Thus, it will affect the process and meaning. Hartono [6] stated that the level of acceptance and readability of metaphors are higher than idioms. Knowledge on reference (context) in its connection to texts became a crucial factor.

Being one of the ethnics rich with traditions, Minangkabau is also rich with expressions. Figurative language is one of the important elements in social interactions in Minangkabau. Lindawati [7] said Minangkabau people use figurative language to maintain politeness when speaking. Minangkabau people use figurative language to convey their thoughts, during debates, or while giving advices to other people.

It is safe to say that figurative language is used very commonly in the everyday life of the Minangkabau people. As a product of the tradition in speaking, the function of figurative language for the community is very complex. For Minangkabau people, using a figurative language is not just a way to demonstrate politeness when giving advice and life guidance. However, as time goes by, knowledge and understanding of the figurative language start to diminish. Therefore, efforts to enhance knowledge and understanding of the types of Minangkabau idioms and their meaning are necessary.

\section{RESEARCH METHOD}

Studies on the methods and techniques in understanding idioms have been made. Boers [17]concluded that knowledge of the meaning of the origin of the words in the idiom and the origin of the idiom can help give a whole understanding to the meaning. Also on the same page, Tsiplakou[18]stated that the people with the same mother tongue will have the ability to easily understand the implicit meaning contained in the idiom that came from their group (location, ethnic, language). Meanwhile, Geeraert [19] said it would be easier to understand the meaning by modifying the idiom while still connecting it to its true to its context.

The studies above are carried out with the intention to preserve the existence of the complex and symbolic idioms in conversations due to the messages contained in them. Efforts to manage idioms to make them easy to understand have been conducted through several ways. One of the alternatives is to transform them into visual forms. The visual form (comics) can pull the readers into an indirect interaction with the writer to understand the message in the text. The comic visual form is also the right learning tool for readers' to develop knowledge and interest on certain things[20]-[24]. In its context to the Minangkabau idioms, the transformation of idioms into a visual form (comics) can bring readers closer to the tradition and to understand the concept of alam takambang jadi guru [25], [26].

One attempt to reintroduce the meaning of the Minangkabau idiom is through transformation into an image form. This research collects idioms that are directly related to daily life. Selected idioms that carry moral contents and daily life guidance are transformed into visual forms, comic strips, and illustrations. The first step is interpreting the idiom. Visualization of the meaning of the Minangkabau idiom based on the interpretations is done in a form that is easily accepted by readers of all ages. 


\section{RESULT AND DISCUSSION}

In practice, idioms are not only used in non-formal conversations. They are also used in formal speeches to convey intentions and purposes as often seen in events or activities related to culture and tradition such as in marriages. Idioms and figurative language are often used in ceremonies to propose a marriage and during wedding events. The use of figurative language is interesting and entertaining for the people as they can reduce tensions and yet in a polite manner. Nowadays, the use of figurative language has spread to formal academic and nonacademic speeches. The use of figurative language in academic and non-academic contexts is to show the humorous side of the speaker [8].

For the people of Minangkabau, using figurative language is very common and is a daily scene in delivering their intentions and purposes. According to Zabadi [9], Minangkabau people seemed to have an unwritten agreement in using and understanding idioms. Bakato kieh is one of the philosophies in speaking to teach harmony in groups.

According to Navis [10], figurative language in Minangkabau is categorized as sayings, proverbs, mamangan, pituah, pameo, petitih. Navis made the categories based on forms, functions and meanings. Saying is a two-word figurative language. A proverb is a saying added with a certain word. Mamangan is a figurative language that contain lessons on life, instructions, advices, and restrictions. Pituah is figurative language that contain lessons about ethics. Pameo is figurative language that contain contradictions. Petitih is figurative language that carry the meaning of equality.

The categories made by Navis shows that the Minangkabau people are rich with figurative language. The message contained in each form of idiom show the complexity of the figurative language and they also show how they absorb the Minangkabau philosophy alam takambang jadi guru.

Minangkabau idioms are known to contain magic elements related to the belief of their people. For them, idioms possess the power to describe the relationship between the human life and the nature around them [11]; professions, marriages, traditional healings, households, phenomena of nature, and death[12]; and all that are always connected to the lessons about personal lives and community [13]-[16].

On the other hand, it is also often found that the meaning of the idioms used didn't match the intentions and purposes. Lindawati [7] said many were very different and even far from the true meaning (mamangan). She added that because of the disharmony of the construction of meaning and their contradictory, the meaning of the idiom tends to differ from the intentions and purposes. As an example, duduak sorang basampik-sampik duduak basamo balapang-lapang' feeling cramped sitting alone, but roomy when sitting together '. Logically, the idiom sounds contradictive and odd. The construction of sorang 'alone 'is associated with sampik 'cramped'and basamo 'together' with lapang 'roomy'.

Previous studies on Minangkabau idioms showed that the level of knowledge of the young Minangkabau generation on lexicons and specific Minangkabau terms is much lower compared to those of the older generations. It's likely that the preference to speak the Minangkabau language also brought an impact towards the young generations' level of knowledge on Minangkabau proverbs and idioms. This is somehow ironic because for the Minangkabau people, they should converse using parables and negotiate using figurative language [16].

The low literacy on vocabularies, group of words, idioms, and their meaning can be minimized by balancing them with the right introductory methods and techniques. In this case, in the form of visual, either stories with pictures, comics or comic strips. 


\subsection{The expression gadang sarawa}

The expression gadang sarawa originated from the words gadang 'big' and sarawa 'pants'. However, the expression didn't mean big pants or big-sized pants. Based on the context, the expression gadang sarawa means cowardice, easily afraid, or arrogant.
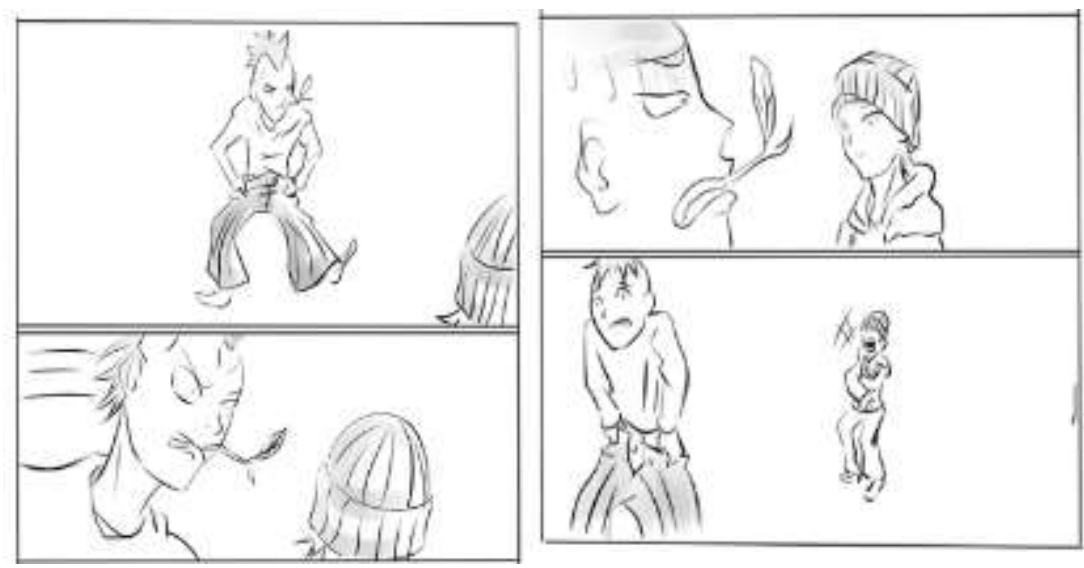

Figure 1.Comic strip on the expression gadang sarawa

For Minangkabau people, pants are not only meant to cover skins but they are also used to show social status. The expression also tells the Minangkabau to conduct themselves and to behave appropriately [27]-[30].

The expression contained advice to men to be brave in dealing with matters, to not be afraid, it teaches them about self-control and that they don't run away from problems. The expression also teaches that a coward man would be a laughing stock. The visual on (Figure 1) would help readers to easily understand the meaning of the expression gadang sarawa which means a coward.

\subsection{The expression duduak ubi}

Ubi (cassava) is very close to the heart of the Minangkabau people. Aside from coconuts, cassava is tuber where people can use every part of it. The Minangkabau people love to eat cassava leaves as their vegetable dish and use the cassava to create various types of traditional food.

The expression duduak ubi 'sitting like cassava', does not mean sitting pensive and stay quiet like a cassava plant. It has a wider meaning than the words that form the expression, sitting and cassava. It offers several meanings. First, the expression means doing works that should bring in results. Humans should copy the cassava roots which continue to grow bigger despite their invisibility because they are underground. 


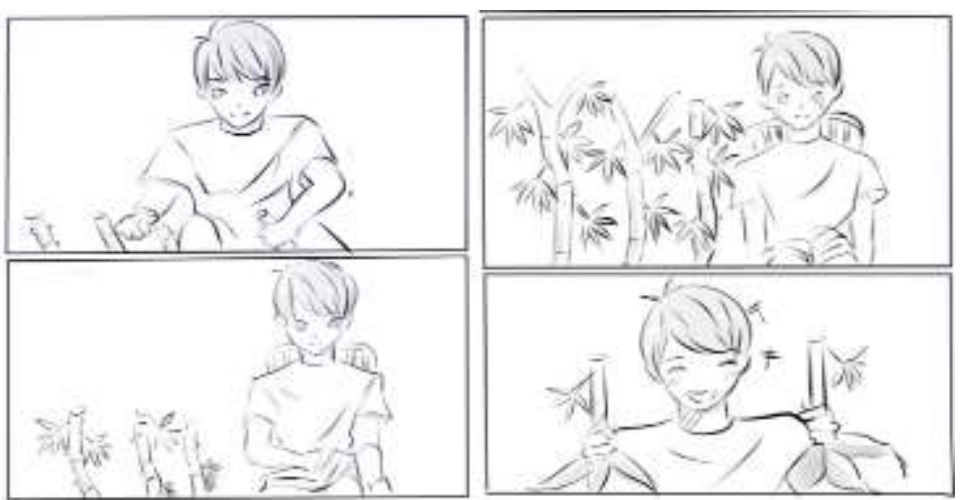

Figure2.Comic strip for the expression duduak $u b i$

The expression is also used to train people to have sensitivity and a critical attitude. Training to have a critical attitude is an advice for children and teenagers so that they are sensitive towards their environment. Sensitivity and critical attitude can be learned from nature such as from the cassava plant. Second, it teaches children and teenagers to control themselves and to not rush when dealing with matters. Third, image building. Children and teenagers are taught to build their image, to always remain calm and to be resourceful to others just like the cassava roots that always keep growing (Figure 2).

\subsection{The expression baliang-baliang di puncak bukik}

The expression baliang-baliang di puncak bukik 'propellers on top of the hills' teaches about how to live in a community. As a description, propellers will start moving when the wind blows. Propellers can also be used to show the wind direction due to its shape.

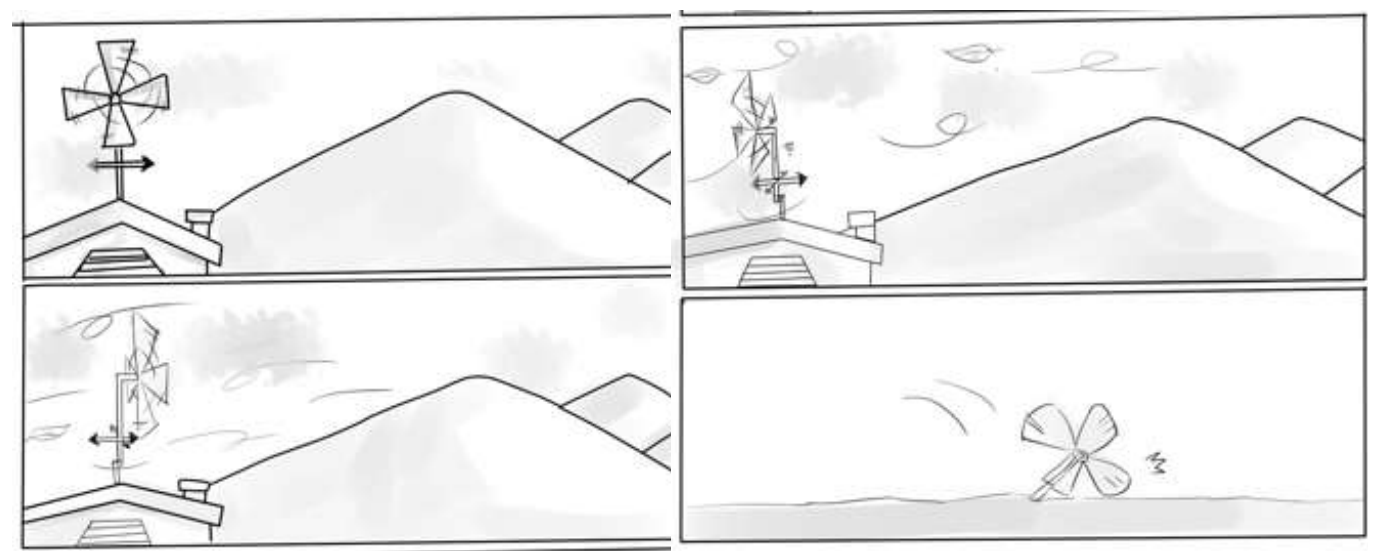

Figure3.Comic strip on the expressionbaliang-baliang di ateh bukik

Given that propellers always follow the direction where the wind blows, the expression is about a person with no principle. This person would go wherever the wind blows. This expression is similar to another Minangkabau idiom, bak pucuak aru, which also means a man 
without principle. This idiom contains advice and guidance to control one self and think before taking any action. The expression also teaches one to have solidarity, to not only think of only one self and disregard other people as it will only harm yourself. The messages are described in the visualization of the broken propellers by a strong wind (Figure 3 ).

Through visualization, the transformation from text to pictures, traditional expressions are hoped to be more acceptable and easier to understand for readers, especially children [31]. They can be used not only as a learning topic on traditional contents but also as a learning topic on Minangkabau contents.

\section{CONCLUSIONS}

The transformation of the Minangkabau idioms into visual comic strips was not meant to reduce the meaning contained in the expressions. On the other hand, the transformation is hoped to pull the young generation closer to the traditional cultural products. The contents in the Minangkabau idioms should not diminish or become extinct because less and less people are using them. The transformation is part of the efforts to transfer knowledge and understanding about the lessons of life of the Minangkabau people who absorb the philosophy alam takambang jadi guru.

\section{REFERENCES}

[1] R. O. Utami and A. Munir, "Problems In Understanding Idiomatic Expressions By Senior High School Students," Retain, Vol. 2, No. 2, 2014.

[2] H. A. Pratiwi, "Idioms in the National News Rubric Category of Education on cnnindonesia.com," Pena Literasi, vol. 1, no. 1, pp. 1-16, May 2018.

[3] N. W. Sartini, "Menggali Nilai Kearifan lokal Budaya Jawa Lewat Ungkapan (Bebasan, Saloka, dan Peribahasa)," Logat Jurnal Ilmiah Bahasa dan Sastra, vol. V, no. 1, pp. 28-37, 2009.

[4] J. T. Haryanto, "Kontribusi Ungkapan Tradisional Dalam Membangun Kerukunan Beragama," Walisongo: Jurnal Penelitian Sosial Keagamaan, vol. 21, no. 2, pp. 365392, Dec. 2013.

[5] S. I. Hamid and T. Istianti, "Rekonstruksi Nilai Moral Kewarganegaraan Berdasar Analisis Semantik Terhadap Ungkapan Kultural Masyarakat Sunda," Cakrawala Dini: Jurnal Pendidikan Anak Usia Dini, vol. 3, no. 2, Mar. 2018.

[6] R. Hartono, "Penerjemahan Idiom Dan Gaya Bahasa (Metafora, Kiasan, Personifikasi, Dan Aliterasi) Dalam Novel"To Kill A Mockingbird"Karya Harper Lee Dari Bahasa Inggris Ke Bahasa Indonesia (Pendekatan Kritik Holistik)," Universitas Sebelas Maret, 2011.

[7] Lindawati, "Mamangan Minangkabau (Sebuah Tinjauan Semiotik)," Wacana Etnik, vol. 3, no. 2, 2012.

[8] I. K. D. Laksana, "Bahasa Kias Dan Penggunaannya Dalam Tuturan Resmi," In Prosiding Seminar Nasional Sastra Dan Budaya III, 2018.

[9] F. Zabadi, "Ungkapan Idiomatis Dalam Budaya Masyarakat Minangkabau," Widyariset, vol. 12, no. 3, pp. 53-60, Dec. 2009.

[10] A. A. Navis, Alam Terkembang Jadi Guru. Jakarta: Grafitti Press, 1984.

[11] A. Alfianto, H. E. Thahar, and Z. Zulfikarni, "Ungkapan Kepercayaan Rakyat di Kenagarian Tapan Kabupaten Pesisir Selatan," MARKAH Jurnal Pendidikan Bahasa dan Sastra Indonesia, vol. 1, no. 2, pp. 318-323, 2013. 
[12] R. Atriyanti, A. Amir, and H. Hamidin, "Ungkapan Kepercayaan Rakyat Minangkabau di Parak Gadang Kecamatan Padang Timur," MARKAH Jurnal Pendidikan Bahasa dan Sastra Indonesia, vol. 1, no. 1, pp. 204-213, 2012.

[13] L. Marrini, H. E. Thahar, and H. Hamidin, "Ungkapan Kiasan Minangkabau di Desa Talawi Hilir Kecamatan Talawi Kota Sawahlunto," MARKAH Jurnal Pendidikan Bahasa dan Sastra Indonesia, vol. 1, no. 1, pp. 186-194, 2012.

[14] H. Andheska, "Kearifan Lokal Masyarakat Minangkabau Dalam Ungkapan Kepercayaan Rakyat," Basindo: jurnal kajian bahasa, sastra Indonesia, dan pembelajarannya, vol. 2, no. 1, pp. 22-28, Jul. 2018.

[15] R. Almos, Pramono, and Reniwati, "Pantun dan Pepatah-Petitih Minangkabau Berleksikon Flora dan Fauna,” Adabiyyat, vol. XIII, no. 2, pp. 300-317, 2014.

[16] Oktavianus, "Nilai Budaya dalam Ungkapan Minangkabau," Linguistik Indonesia, vol. 24, no. 1, pp. 115-129, 2006.

[17] F. Boers, J. Eyckmans, and H. Stengers, "Presenting figurative idioms with a touch of etymology: more than mere mnemonics?," Language Teaching Research, vol. 11, no. 1, pp. 43-62, Jan. 2007.

[18] S. Tsiplakou, "Which dialect, what literacy?," in Proceedings of the 7th International Conference on Modern Greek Dialects and Linguistic Theory, 2019, pp. 28-37.

[19] K. Geeraert, R. Harald Baayen, and J. Newman, "Understanding Idiomatic Variation," in Proceedings of the 13th Workshop on Multiword Expressions (MWE 2017), 2017, pp. 80-90.

[20] H. N. Hidayat, “Alih Media Pembelajaran Bahasa dan Sastra Daerah,” in Prosiding Seminar Nasional Bahasa Ibu, Bahasa Daerah sebagai Sumber Kearifan Bangsa, 2013, p. 42.

[21] T. Immerry and H. N. Hidayat, "Mang'a, Komik, dan Literasi," in Jepang dan Indonesia dalam Perspektif Humaniora, 2018.

[22] E. Ega And H. D. Waluyanto, "Perancangan Komik Strip Untuk Meningkatkan Semangat Kewirausahaan,” Jurnal DKV Adiwarna, vol. 1, no. 4, p. 12, Jul. 2014.

[23] M. Pritandhari, "Penerapan Komik Strip Sebagai Media Pembelajaran Mata Kuliah Manajemen Keuangan Mahasiswa Universitas Muhammadiyah Metro," Promosi (Jurnal Pendidikan Ekonomi), vol. 4, no. 2, Dec. 2016.

[24] S. S. REYES, "The Komiks and Retelling the Lore of the Folk," Philippine Studies, vol. 57, no. 3, pp. 389-417, 2009.

[25] T. Immerry and F. Dahlan, "Ungkapan Minangkabau: Upaya Visualisasi Alam Takambang," Suluah, vol. 18, no. 22, 2016.

[26] T. Immerry and F. Dahlan, "Teaching Literature Through Comic Strip," in The 4th International Conference ASEAN Comparative Education Research Network (ACER$N$-2016), 2016, pp. 1609-1613.

[27] N. Amelia, N. A. Manaf, and N. Juita, "Nama Dan Makna Bagian-Bagian Pakaian Penghulu Minangkabau Di Kenagarian Kacang Kecamatan X Koto Singkarak Kabupaten Solok,” Bahasa dan Sastra, vol. 5, no. 1, pp. 134-148, 2017.

[28] Y. Asri, "Refleksi Ideologi Wanita Minangkabau Dalam Novel Negeri Perempuan Karya Wisran Hadi," Humaniora, vol. 25, no. 1, pp. 69-81, 2013.

[29] R. Almos, "Makna Pantang Dalam Bahasa Minangkabau," Linguistika Kultura, vol. 2, no. 3, Mar. 2009.

[30] Ariusmedi, "Bahasa Rupa pada Pakaian Penghulu Minangkabau," Humanus, vol. 10, no. 1, p. 9, Jul. 2012.

[31] K. Saddhono, "Language of Coastal Communities in the Northern Coast of Central 
Java: Sociolinguistic Studies in Cultural Integration Maritime-Agrarian Perspective." Adv. Sci. Let. vol. 23 no.10 pp 10054-10056, 2017 